\title{
PLOD2 Gene
}

National Cancer Institute

\section{Source}

National Cancer Institute. PLOD2 Gene. NCI Thesaurus. Code C162519.

This gene is involved in the synthesis of hydroxylysine, which promotes collagen

glycosylation and increases the stability of cross-linked collag en fibrils. 